\title{
How to Make Exemplarity with Secret Virtues: Funeral Sermons and Their Challenges in Early Modern France
}

\author{
Anne Régent-Susini
}

Funeral sermons were immensely popular throughout seventeenth-century Europe. In France, such public speeches (oraisons funèbres) constituted major cultural, religious, and often political events. The sermons were sustained by a complex institutional organisation and, at least in the case of the most prestigious of them, embedded in a multimodal semiotic framework. As such, they do not seem to have much to do with privacy. They belong to a time when death was not viewed as a private event, especially when a public figure was concerned. ${ }^{1}$ In those cases, funeral ceremonies often entailed a spectacular decoration of the church as well as public advertising and public reports in newspapers. As to their content, by their very nature, funeral sermons are situated at the intersection of biography and history, of individuals and communities, of particular actions and public deeds. However, they target communal memory and therefore mobilise shared memories and mostly deal with public or semi-public biographical episodes. As official or semi-official epideictic speeches, they primarily address the community rather than individuals, which explains why they seem to exclude privacy. Furthermore, they do not describe the specific aspect of each person, but rather his or her sense of community. By collectively re-enacting the personal experience of loss and death, they are meant, in a typically epideictic dynamics, to sustain the unity of the living as a group that shares the same values and representations. ${ }^{2}$ They

1 The research bibliography on death in early modern France is enormous. Not to mention art historians and literature scholars, extensive historical research of the 1960s and 1970s investigated death in medieval and early modern France. With its long timespan, La Mort et l'Occident de 1300 à nos jours (Paris: 1983) by Michel Vovelle can be considered a major output of these approaches that mostly pertain to cultural history. More focused on the rituals surrounding the death of kings and their politico-theological dimensions, the work of E. Kantorowicz and R. Giesey has been debated by scholars like A. Boureau, M. Fogel, J.-M. Le Gall, and J.-C. Bonnet.

2 On the argumentative dimension of epideictic speeches, see Dominicy M. - Frédéric M., "Introduction. L'éloge, le blâme, et le genre épidictique", in Dominicy M. - Frédéric M. (eds.), La Mise en scène des valeurs. La rhétorique de l'éloge et du blâme (Paris: 2001) 11-17; Danblon E., 
constitute collective experiences that reinforce the unity of the group and intentionally transcend private emotions of grief, sadness, and fear, aiming towards the regeneration of the community.

The different modes of publication, understood as the ways in which sermons were made public, afforded them different kinds of readership. On occasion, oral performances were recorded in private or semi-private notes and diaries and in private letters. Furthermore, the printed versions intended not only to extend the praise of the deceased beyond the spatio-temporal coordinates of the oral performance: the print also made the speech (and even its setting) available for private purposes, especially personal meditation. In this regard, and although the communal dimension of Catholic funeral sermons generally remained strong, their reading could prompt, guide, and, more generally, offer a framework for private devotion. This meditative dimension was probably the main function of smaller and cheaper books in-8 or in-12. A Lyon bookseller's catalogue indicates that, while in-4 funeral sermons cost 20 sols, an octavo was sold for only five sols. ${ }^{3}$ Indeed, the smaller formats were used for the actual funeral sermon, but also for presenting various other elements regarding the dead or the ceremony. Some of them, however, included only the funeral sermon as a support for private meditation or, more broadly speaking, for private devotion. ${ }^{4}$ The in-4 books could also be used in private, but they were often offered as gifts. Thus, the famous court preacher Jacques-Bénigne Bossuet (1627-1704) forwarded his sermons for Henriette de France (1609-1669) and

"La rationalité du discours épidictique", in Dominicy - Frédéric (eds.), La Mise en scène des valeurs 19-47. Indeed, as Marianne Doury shows, there is no need for an actual opponent for an argumentation to be displayed, see her "Prêcher un convaincu. Pourquoi argumente-t-on quand on est tous d'accord?", in Roque G. - Nettel A.L. (eds.), Persuasion et argumentation (Paris: 2015) 113.

3 See "Livres nouveaux qui se trouveront à Lyon chez le Sieur Amaulry; depuis l'année 1678, jusqu'à présent", bound with Mercure Galant dédié à Monseigneur le Dauphin. Avril 1685 (Lyon, Thomas Amaulry: 1685), located at the Bibliothèque de la Ville de Lyon. An iconographic counterpart of those funeral sermons, Ménestrier's Décorations funèbres cost a bit more - 20 sols for two volumes in octavo, but those books included many more illustrations.

4 In early modern Europe and even later, smaller formats (in- $8^{\circ}$ and in- $12^{\circ}$ ), with few, if any, illustrations (mostly allegorical frontispieces or portraits of the author) were the most frequently used format for devotional books. See Martin P., Une religion des livres (1640-1850) (Paris: 2003) 128. 
her daughter Henriette d'Angleterre (1644-1670) to Armand Jean le Bouthillier de Rancé (1626-1700), the founder of the Cistercian monastery of La Trappe:

Je vous envoie deux oraisons funèbres qui parce qu'elles font voir le néant du monde peuvent avoir place parmi les livres d'un solitaire; en tout cas, on peut les regarder comme deux têtes de mort assez touchantes. ${ }^{5}$

I am sending you two funeral sermons, which, because they emphasise the world's nothingness, can be included among the books of a solitaire; in any case, they can be regarded as two skulls that are quite moving.

This private and devotional function is confirmed by the presence of funeral sermons in bound recueils factices, that is, compilations of various manuscripts, printed pages, or entire texts bound together by a particular individual. Unlike the recueils d'éditeurs, such personal compilations were usually oneof-a-kind: the owner of the compiled documents had gathered them and had them bound together. Generally, these compilations were intended for private reading although sometimes they could be read with friends or family: in some instances, they circulated to wider audiences. Over time, the bound documents were often dismantled. Despite this unfortunate circumstance, the surviving recueils factices show that the life of a funeral sermon did not end with its performance. In manuscript or in print, the preacher's words could be read for personal reasons and appropriated according to them, thereby influencing personal lives and, more specifically, fuelling one's own and other people's private meditations on death.

This dual appropriation of the speech - both collective and individual - is anticipated by the way in which the funeral orator addresses his audience. The usual term was 'Messieurs' ('Gentlemen'): 'avouez, Messieurs', 'Voyez, je vous prie', 'Voyez, Messieurs.' ${ }^{6}$ At strategic moments, the orator can choose another address, such as 'Christians', which can be interpreted in terms of what the cultural anthropologist Edward Hall called proxemics, ${ }^{7}$ dividing social distance into four increasingly wide spheres:

5 Letter from Jacques-Bénigne Bossuet to Rancé of 30 October 1682, in Bossuet JacquesBénigne, Correspondance, eds. Ch. Urbain - É. Lévesque, vol. 2 (Paris: 19o9-1925) 331. All translations are mine, unless otherwise stated.

6 See, for instance, Mascaron Jules, Oraison funèbre de Henriette d'Angleterre, in Les Oraisons funèbres, ed. B. Gallina (Fasano - Paris: 2002) 154-155.

7 Hall defines proxemics as 'the interrelated observations and theories dealing with man's use of space as a specialised elaboration of culture'. Hall E., The Hidden Dimension (Garden City, NY: 1966) 1. 
1) The intimate sphere, for intimate friends and relatives $(=0,5 \mathrm{~m})$.

2) The personal sphere, for acquaintances $(=1 \mathrm{~m})$.

3) The social sphere, for oral interactions with strangers $(=4 \mathrm{~m})$.

4) The public sphere, impersonal and anonymous (acoustic horizon).

Although proxemics is usually considered a subcategory of the study of nonverbal communication, several French sociolinguists have suggested that these frames could be used in a symbolic way to study vocative (or appellative) nominal groups, called 'terms of address'. ${ }^{8}$ Such terms, then, specify how far from the addressee the speaker stands or wishes to stand. Whenever the orator addressed his audience as 'Gentlemen', he kept his speech in the public and social sphere. Following the linguist Dominique Lagorgette, such public addresses can be subsumed under the category of 'functional spheres'. Addressing his audience as 'Christians', the orator positions his speech within functional spheres, but he also opens them up to more 'personal spheres', which for Lagorgette subsume Hall's 'intimate' and 'private' spheres. Indeed, the fluid relationship that the preacher establishes with the listener (and, subsequently, with the reader) is exactly where functional spheres merge with personal spheres. Indeed, this dimension of the speeches' reception seems to challenge the dichotomy between 'public' and 'private'.

\section{Biographical Content: Between Public and Private}

This challenge also applies to the funeral sermons' biographical content. As a matter of fact, these speeches were not written and performed by the dead person's confessor, who supposedly knew his or her inner dispositions, but rather by a preacher who had to praise visible deeds and triumphs: they aimed at celebrating the glory of the deceased, his or her visible qualities that were known to all and supposedly missed by all. In most cases, the orator did not even know the deceased personally; he might have been an occasional preacher appointed to this task for reasons to do with prestige or institutional connections. This is why he often had to rely on someone else's account to document his speech. We know several biographies that were written as preparatory sources for funeral sermons, but their author could in no way be the dead person's confessor - for self-evident reasons of what we would call professional secrecy. This also means that funeral sermons could in no way claim

8 See Lagorgette D., "Termes d'adresse et insultes: discours sur l'autre ou sur moi?", in Ayres-Bennett W. - Jones M.C. (eds.), The French Language and Questions of Identity (Cambridge: 2007) 116-128. 
to search the heart of the deceased: they were exclusively relegated to exteriority while they simultaneously posited that the inner life of the deceased is what truly matters: the bottom of the heart, in all its inaccessibility, stipulates the true space of salvation. ${ }^{9}$ There was indeed, in the course of the seventeenth century, a growing feeling that Christian virtue had little to do with outer glory. Of course, this was by no means an entirely new viewpoint but one as old as Christianity itself. The figure of King David, ${ }^{10}$ for instance, embodied both the triumphant and public face of virtue as well as its more private, anxious, and penitent aspects. In the second half of the seventeenth century, this problem of the potential discrepancy between a virtuous public image and a darker inner self became all the more pressing because suspicions dogged all forms of human glory: to celebrate the Grand Condé, should one recall his glorious youth on the battlefields or call attention to his private and devout retreat in Chantilly?11

The growing suspicion towards 'outer' values probably explains why editors sometimes had the testimonies of the preacher and the confessor published together: this resulted in small books, typically of a duodecimo format, which included both a funeral sermon and a biographical account by the confessor, alongside other documents. An example of such a composite work is the volume that includes the funeral sermon of Queen Marie-Thérèse by Jacques-Bénigne Bossuet and an "Abrégé de sa vie" by Father Bonaventure de Soria, the queen's confessor. This work also comprises depictions of the funeral ceremony in the royal basilica of Saint-Denis and Marie-Thérèse's mausoleum in Notre-Dame de Paris. ${ }^{12}$ Another book pays tribute to the Dauphin and the Dauphine: Louis XIV's grandson and his wife both died of measles during the same week

9 On this topical spatialisation of inner life, see Papasogli B., Figures de l'espace intérieur au XVII ${ }^{e}$ siècle, Le fond du coeur (Paris: 2000).

10 On the ambivalence of David's figure, both triumphant and anxiously penitent, in French seventeenth-century music, see Bennet P., "Hearing King David in Early Modern France: Politics, Prayer, and Louis XIII's Musique de la Chambre", Journal of the American Musicological Society 69.1 (2016) 47-109.

11 René Rapin's two last works, Du Grand ou du sublime (1686) and Le Magnanime ou l'éloge du prince de Condé (1687) question this new choice between the two heroic models. See Bruun's contribution to this volume.

12 Soria Bonaventure de, Abrégé de la vie de très-auguste et très vertueuse princesse Marie Térèse d'Austriche, reyne de France et de Navarre, par le R.P. Bonnaventure de Soria, son confesseur, et son Oraison funèbre prononcée à Saint-Denis le 1er de septembre 1683 par Messire Jacques-Bénigne Bossuet, évesque de Meaux. Description de la décoration funèbre de Saint-Denis pour les obsèques de la reyne. Mausolée dressé dans l'église de Nostre-Dame de Paris au service solennel célébré pour le repos de l'âme de la reyne (Paris, R. Roulland: 1683). 
of February 1712. It contains their respective funeral sermons as well as a Recueil des Vertus du Duc de Bourgogne, \& ensuite Dauphin, pour servir à l'Éducation d'un Grand Prince by the Jesuit Martineau, ${ }^{13}$ who was the Dauphin's confessor. Although it seems that Martineau found such a publication slightly questionable, he nevertheless justified it in the following manner:

Je ne crois pas qu'on me fasse un crime de lever le sceau sous lequel sa modestie et son humilité ont tenu caché beaucoup de choses que je rapporterai; c'est un trésor qu'il est permis d'ouvrir, maintenant que nous pouvons regarder comme un bien public les dons de grâce \& de miséricorde que Dieu avait mis en lui. Il n'est plus à craindre qu'il en perde le mérite par des louanges prématurées; il est temps que chacun en profite par une fidèle imitation. ${ }^{14}$

I do not believe I will be seen as committing a crime by lifting the seal [of confession] under which his modesty and his humility have kept hidden the many things I will report. Opening up this treasure is allowed, now that we can regard as a public good the gifts of grace and mercy, which God had placed in him. It is not to be feared that he would lose their merit by premature praise anymore; now is time that everyone benefits from them by an accurate imitation.

Firstly, Martineau repeats a topos of funeral sermons: one can legitimately praise the deceased because the dead cannot take pride in it. Secondly, he

13 Gaillard Honoré, "Oraison funèbre de Très-Haut, Très-Puissant et Excellent Prince Monseigneur Louis Dauphin; et de Très-Haute, Très-Puissante et Excellente Princesse Madame Marie Adélaïde de Savoye, son Epouse, prononcée dans l'Église de Paris, le dixième Mai 1712", in Oraisons funèbres des dauphins de France et de la Dauphine, Par Mr l'Evêque d'Alet, le Père Gaillard, le Père de la Rue, \&cc. On y a joint le Recueil des Vertus du Duc de Bourgogne, \& ensuite Dauphin, pour servir à l'Education d'un Grand Prince, Par le R.P. Martineau son Confesseur (Amsterdam, J. Desbordes \& L. Renard: 1713).

14 Martineau Isaac, Recueil des vertus de Louis de France, Duc de Bourgogne, \& ensuite Dauphin (Paris, Jean Mariette: 1712) 7. When Paul Lejeune (1592-1664), who wrote such Relations or accounts, decided to publish spiritual letters, he justified this decision in similar terms: 'Je suis fâché que des personnes grandes en vérité, devant les yeux de Dieu et des hommes, me lient si fort les mains et m'obligent à garder le secret de leurs lettres, ou plutôt de leurs vertus' ('I deplore that people who are great in God's and in everyone's eyes, tie my hands so strongly and force me to keep their letters or, should I say, their virtues, secret'). By revealing this 'secret', the Jesuit narrator aims at celebrating God's grace in New France, while strategically advertising the Jesuit missions as a utopian social space, see Goujon P., Les Politiques de l'âme. Direction spirituelle et jésuites français à l'époque moderne (Paris: 2019) 107. 
claims that death moves the boundaries between public and private and, eventually, turns everything about the dead person into a 'public good'. This last point is to be understood quite literally. If those who were called les Grands ('the Great') are 'public goods', it is because their greatness, ultimately, does not belong to them. This is especially true for princes and kings, and it is often linked to the topos of 'noblesse oblige', that is, privilege entails responsibility to society. This maxim was inseparable from the intrinsically hyper-visible dimension of all 'great people':

Les princes ont plus de devoirs à remplir que le reste des hommes. Plus ils sont grands, plus ils doivent de grands exemples. Ils sont en spectacle aux regards comme aux hommages de la multitude. ${ }^{15}$

Princes have more duties to fulfil than other men. The greater they are, the more they have to set great examples. They are on display to both the gaze and the praise of the crowd.

This topos can be found in many French early modern funeral sermons. However, it is probably significant that at the very end of that period Jean-Baptiste Massillon (1663-1742), a famous Oratorian preacher, returns to this commonplace but gives it a very pragmatic interpretation. As the last of the 'neoclassical' preachers and the first of the Enlightenment preachers, Massillon's preaching shares many common features with the previous generation of court preachers typical of Louis XIV's reign but also introduces new themes. Thus, the Oratorian takes a new interest in what will become the dichotomy between public and private life. If all Grands have to be more exemplary than members of the lower strata of society, he avers, it is not only because they, more than others, have to set good examples: it is also because none of their actions can remain unknown since they are public figures:

Nos chutes se cachent sous l'obscurité de notre destinée; mais qu'offrirait notre vie aux yeux du public, si elle était en spectacle comme la leur? C'est un malheur de leur rang, que souvent avec plus d'innocence que nous, ils ne sauraient jouir comme nous de l'impunité d'un seul de leurs vices. ${ }^{16}$

\footnotetext{
15 Massillon Jean-Baptiste, "Oraison funèbre de Madame, Duchesse d'Orléans", in Massillon Jean-Baptiste, Sermons de M. Massillon, Évêque de Clermont, vol. 9, Oraisons funèbres et Professions religieuses (Paris, chez les Frères Estienne: 1775) 193. 
Our shortcomings are hidden by the obscurity of our destiny. For what would our life present to the public's eyes, if it, like their lives, was on display? This misfortune follows from their rank: unlike us, they cannot enjoy the impunity of a single vice, even though they are often more innocent than we are.

Being a Grand means having no privacy - and this has to be understood on an eschatological as well as a societal level. Just as God sees all of our lives, the people see all aspects of the life of the Grands. In another funeral sermon, Massillon apparently adopts a more pessimistic approach, although he actually claims that the deceased broke this general rule:

Rien n'est plus rare pour les grands que les vertus domestiques. La vie privée est presque toujours le point de vue le moins favorable à leur gloire. Au dehors, le rang, les hommages, les regards publics qui les environnent, les gardent, pour ainsi dire, contre eux-mêmes. Toujours en spectacle, ils représentent: ils ne se montrent pas tel qu'ils sont. Dans l'enceinte de leur palais, renfermés avec leurs humeurs et leurs caprices au milieu d'un petit nombre de témoins domestiques et accoutumés, le personnage cesse, et l'homme prend sa place et se développe. ${ }^{17}$

Nothing is less common among les grands than domestic virtues. Private life is usually the least favourable vantage point for their glory. Outside, rank, tributes, public gaze all around them protect them, so to say, against themselves. Always on display, they perform: they do not show themselves as they are. Inside their palaces, however, alone with their temper and their whims among a small number of domestic witnesses accustomed to them, the persona disappears, and the man replaces him and grows.

Privacy thus becomes the only sphere where virtue can be authenticated and where the evolution towards a domestic or even bourgeois virtue has begun: the only place where genuine virtue can be witnessed and assessed is in the home and within the family. Among the many seventeenth-century authors influenced by Augustinianism, suspicions grew towards all public virtues. Such suspicions were especially characteristic of, but not exclusive to, the 'French moralists' (La Rochefoucauld, La Bruyère, Pascal), as they were later named. This suspicion called into question all visible signs of virtue and,

17 Massillon, “Oraison funèbre de Madame, Duchesse d'Orléans" 189. 
gradually, undermined the heroic ideal that was still so powerful in the early seventeenth century. Indeed, edifying manifestations of virtues were more and more perceived as disconnected from inner feelings and qualities. In this evolution, undoubtedly posing a challenge to funeral orators, the representation of private virtues could appear as a viable compromise that preserved exemplary figures. In a world where all virtuous behaviour was suspected of being prompted by pride or libido dominandi (desire to dominate), virtuous deeds performed in private offered a kind of semi-exteriority - an intermediary ethical space - that was less suspect of questionable motives, although such deeds did not evade the risk of self-illusion. Therefore, some funeral sermons began ascribing special value to domestic virtues, considering them more reliable moral signs than public virtues. Thus, the famous preacher and Bishop of Nîmes, Esprit Fléchier (1632-1710), conjures up the 'vie privée' of Guillaume de Lamoignon by preterition: 'Que ne puis-je vous le montrer [...] Que ne puis-je vous le représenter ... Vous le verriez [...]' ('that I cannot show him to you [...] that I cannot represent him to you ... You would see him [...]'). This celebration of the deceased President is still quite distinct from our notion of privacy, but it is explicitly opposed to the eyes of the public, to the hustle and bustle of the city, and to the troubles of negotium:

Peut-être doutez-vous, Messieurs, qu'étant éloigné des yeux du public, il fût encore égal à lui-même? Entrons dans sa vie privée. Que ne puis-je vous le montrer parmi ce nombre de gens choisis, qui formaient chez lui une Assemblée, que le savoir, la politesse, l'honnêteté, rendaient aussi agréable qu'utile? [...] Que ne puis-je vous le représenter tel qu'il était, lorsqu'après un long et pénible travail, loin du bruit de la ville et du tumulte des affaires, il allait se décharger du poids de sa dignité, \& jouir d'un noble repos dans sa retraite de Basville? [...] Vous le verriez recevant une foule d'amis, comme si chacun eût été le seul, distinguant les uns par la qualité, les autres par le mérite, s'accommodant à tous \& ne se préférant à personne. ${ }^{18}$

You will maybe doubt, Gentlemen, that far from the eyes of the public he would remain the same? Let's enter his private life. If only I could show him to you among those chosen people, who formed at his home an Assembly which knowledge, politeness, civility made as pleasant as 
it was profitable? [...] If only I could show him to you as he was, when after long and hard work, far from the hustle and bustle of the city and the turmoil of affairs, he let go of the weight of his dignity and enjoyed a noble rest in this retreat in Basville? [...] You would see him welcoming a number of guests, you would see how he distinguished some of them by their quality, some of them by their merit, how he adapted to all and gave preference to none.

This 'vie privée' is a space of learned friendship, where a 'number of chosen people' is no longer a group but a reunion of individuals, each of whom, however, receives unique attention. With regard to the ethical space, Massillon takes a step further in transferring virtuous deeds from the public to the private domain. Praising the Prince of Conti, he emphasises his virtue not only in public, but also at home:

Et quand je dis devant les hommes, Messieurs, ne pensez pas que se ménageant, comme tant d'autres, l'estime du public, par les dehors de la modération \& de la sagesse, il vint se démentir dans l'enceinte des devoirs domestiques; que lassé de soutenir en public le personnage de grand homme, il vint porter parmi les siens les chagrins de la contrainte, $\&$ s'y délasser, par des vices, des apparences de la vertu. ${ }^{19}$

Since I speak before men, Gentlemen, you should not think just of looking for public praise, as so many others do, by displays of moderation and wisdom. Such an individual is going to fail within the sphere of domestic duties. Tired of keeping up the public persona of being a great man, he brings the frustrations from constraining himself to his close relatives: there, he relaxes from virtuous appearances by sinful acts.

Some orators go even further: they address the unreliability of ethical signs in the social world by producing fictional scenes of privacy and typically of private devotion. Celebrating Anne d'Autriche, Jean-Louis de Fromentières thus conjures up the following scene:

Entrez dans son Oratoire, suivez-la dans les cloîtres et dans ses lieux de retraite, surprenez-la, si vous pouvez, lorsque défaite de sa Cour, de cette foule importune, servitude inséparable de la grandeur, elle ne croit plus

19 Massillon Jean-Baptiste, "Oraison funèbre de M. le Prince de Conti", in Massillon, Sermons 93 . 
avoir d'autres yeux que ceux de son Dieu pour témoins de ses actions, lorsque, comme une autre Judith, elle ne s'enferme tout au plus qu'avec de saintes filles dans les solitudes secrètes qu'elle s'est bâtie, fecit sibi secretum cubiculum, in quo cum puellis suis clausa morabatur [Judith 8:5], \& vous verrez que son âme s'abaisse encore plus devant Dieu que son corps; \& vous connaitrez que son esprit dit pour lors plus de choses à Dieu que sa bouche, \& vous avouerez que son cœur honore Dieu mille fois mieux que ses lèvres. ${ }^{20}$

Enter into her Oratory, follow her into the cloisters and the places of retreat, surprise her, if you can, when she finds herself overpowered by her Court, by this troublesome crowd - by a slavery inseparable from greatness - and when she believes that only God's eyes bear witness to her actions; when, just like another Judith, only holy girls accompany her retreat into the secret solitudes that she has built herself, "she made herself a private chamber, in which she abides shut up with her maids". There, you shall see that, before God, her soul humiliates itself even more than her body: you will learn that her mind speaks more to God than her mouth does; you will confess that her heart honours God a thousand times more than her lips do.

In order to prove that the queen's piety is not only external but also deep and intimate, the preacher creates a fiction, which allows the listener (or reader) to see the queen where normally she would not be seen. The sermon shows what is usually invisible to common men, although, strictly speaking, this devotion may be semi-private more than properly private, given the presence of the nuns. However, and this is certainly striking, while the imperative verbs ('entrez', 'suivez', 'surprenez') introduce a hypotyposis (a vivid description of this scene as if it were present before the eyes of the audience), there is actually nothing to be seen but abstractions. How could one visualise her soul humiliating itself even more than her body', or a 'mind speaking to God'? Here, visual rhetoric is about seeing interiority, an inner life, which, by nature, is invisible. ${ }^{21}$

20 Fromentières Jean-Louis de, Oraison funèbre d'Anne d'Autriche, Infante d'Espagne, Reine de France, et Mère du Roi, prononcée dans l'église des Martyrs à Montmartre le 6 mars 1666 (Paris, S. Mabre-Cramoisy: 1666) 10.

21 For Jesuit Pierre Coton (1564-1626), the Oratoire is the very place for private devotional reading. Publicising it by oral preaching and subsequently in print brings this private reading space into the common sphere, see Goujon, Les Politiques de l'âme 151. In Fromentières's funeral sermon, however, neither the audience nor the readers are granted access to what the queen actually read. 
The preacher distinguishes between false and true appearances of virtue by producing an imaginary representation of privacy that is clearly based on the evangelical intertext of Matthew 6:6: 'But thou, when thou prayest, enter into thy closet, and when thou hast shut thy door, pray to thy Father which is in secret'.22 Thus, the preacher portrays an otherworldly virtue and its deceiving appearances. The public nature of a queen's piety, ${ }^{23}$ which, supposedly, has eschatological consequences for the entire kingdom, is linked to an understanding that, although not new, grows stronger from the mid-seventeenth century and requires all true virtues to remain unpublished.

Early modern funeral sermons thus help us reflect upon the extent to which privacy, as an ethical space, has a different nature than the public space. Indeed, if funeral sermons offer a good vantage point for the gradual importance given to privacy in early modern ethics, it is because, being fundamentally dedicated to exteriority, they have to tackle a new challenge: how to deal with and detail virtue, when it is increasingly understood as invisible by its nature? Such an evolution makes the orator's task even more delicate, since he, within the French context, has no direct access to privacy. From this time onward, preachers had to negotiate the growing idea that genuine spiritual and ethical virtues are fundamentally private or even secret. This also entails that, eventually, no one can really access them or, to an even lesser degree, evaluate them, which ultimately threatens to jeopardise any kind of exemplarity. To become exemplary, one's virtue has to be visible and even public, but this publication inevitably causes suspicion about the true motivation behind virtuous deeds and the act of disclosing them to the public. In this new and ethically blurred world, the very notion of exemplarity, which presupposes some kind of ethical transparency, becomes intrinsically problematic. In this chiaroscuro bound to replace the radiant stage, where public good deeds shone to all, what would later become the 'private' sphere was an entre-deux: a kind of intermediary space between the secrets of the self and the questionable public displays of virtue.

Therefore, not only do early modern funeral sermons sometimes represent solitary prayer and private devotion, thus giving an unexpected glimpse of these devotional practices or at least of their discursive representation. As a genre,

$22 \quad$ King James Version.

23 See Cosandey F., La Reine de France. Symbole et pouvoir, $X V^{e}-X V I I I^{e}$ siècle (Paris: 200o). 
funeral sermons also help us explore the entanglement of different spheres of privacy and different levels of tension between the public and the private. The printed sermons could be used as official gifts as well as read privately (or semi-privately, in small groups). ${ }^{24}$ This variety of uses seems to correspond to the paradoxical nature of a performance which is both public par excellence and aimed at allowing the listener to go deep into his/her self. Funeral preachers were therefore able to activate those tensions. They could expose publicly and even solemnly private (or even solitary) practices; they could also have their 'official' speech printed, thus offering it to individual appropriations.

As such, funeral sermons offer a unique insight into the complex relationship between two antithetic couples, solitude/community and private/public. The reason why those speeches are fundamentally public (i.e. meant to be publicised) is that they aim at reinforcing a feeling of community, supporting and highlighting the values claimed by the community. As opposed to panegyrics, the representation of solitude as such, though, remains rather rare in those speeches, as if the community could not easily be reflected in a lonely model. ${ }^{25}$ But given the spiritual evolution of seventeenth-century France and the growing suspicion towards the spectacular or even simply public good deeds, funeral sermons gradually tend to include, or even promote, maybe not yet private virtues proper, but virtues practised in private spheres and solitary pious moments. As such, they offer a perfect antidote to arcana historiography, which complacently displayed private passions and secret petty or despicable behaviours hidden behind the curtain of 'great History' ${ }^{26}$ While early seventeenth-century funeral sermons seem to ignore this curtain, their

24 The development of private reading in early modern Europe has been widely studied and it certainly has a particular importance for devotional books, since it accompanies new modes of appropriation of spiritual texts.

25 On the ambivalence of solitude in seventeenth-century religious discourse (setting and preparation for self-knowledge and meditation on the one hand, mark of singularity and pride on the other), see Quantin J.-L., "Paradoxes of Christian Solitude in the Seventeenth Century", Journal of Early Modern Christianity 1.2 (2014) 219-231; Bruun M.B. - Havsteen S.R. - Mejrup K. - Nagelsmit E. - Nørgaard L.C., "Introduction" to this issue, $195^{-205}$. On the intertwining of withdrawal and engagement in early modern Christianity, see, in the same volume, Bruun M.B. - Havsteen S.R. Mejrup K. - Nagelsmit E. - Nørgaard L.C., "Withdrawal and Engagement in the Long Seventeenth Century: Four Case Studies"; as well as Bruun M.B. "A Solitude of Permeable Boundaries: The Abbey of La Trappe between Isolation and Engagement", in Göttler C. Enenkel K.A.E. (eds.), Solitudo: Spaces, Places, and Times of Solitude in Late Medieval and Early Modern Cultures (Leiden: 2018) 451-479.

26 On the illuminating comparison between religious privacy and 'other forms of privacy, be they related to, say, intellectual pursuits in the studiolo, to sexual intimacy, or conversational secrecy', see Bruun's chapter in this volume. 
late seventeenth-century and early eighteenth-century counterparts sometimes lift it - but what is hidden behind it is a greater virtue, and maybe, the preacher implies, the only real one.

\section{Bibliography}

Bennet P., "Hearing King David in Early Modern France:Politics, Prayer, and Louis XIII's Musique de la Chambre", Journal of the American Musicological Society 69.1 (2016) 47-109.

Bossuet, Jacques-Bénigne, Correspondance, ed. Ch. Urbain - É. Lévesque (Paris: 1909-1925).

Bruun M.B. - Havsteen S.R. - Mejrup K. - Nagelsmit E. - Nørgaard L.C., "Introduction”, Journal of Early Modern Christianity 1.2 (2014) 195-205.

Bruun M.B. - Havsteen S.R. - Mejrup K. - Nagelsmit E. - Nørgaard L.C., "Withdrawal and Engagement in the Long Seventeenth Century: Four Case Studies", in Göttler Ch. - Enenkel K.A.E. (eds.), Solitudo: Spaces, Places, and Times of Solitude in Late Medieval and Early Modern Cultures (Boston: 2018) 249-343.

Bruun M.B., "A Solitude of Permeable Boundaries: The Abbey of La Trappe between Isolation and Engagement", in Göttler Ch. - Enenkel K.A.E. (eds.), Solitudo: Spaces, Places, and Times of Solitude in Late Medieval and Early Modern Cultures (Boston: 2018) 451-479.

Cosandey F., La Reine de France. Symbole et pouvoir, $X V^{e}-X V I I I^{e}$ siècle (Paris: 200o).

Dominicy M. - Frédéric M. (eds.), La Mise en scène des valeurs. La rhétorique de l'éloge et du blâme (Paris: 2001).

Doury M., "Prêcher un convaincu. Pourquoi argumente-t-on quand on est tous d'accord?", in Roque G. - Nettel A.L. (eds.), Persuasion et argumentation (Paris: 2015) $103^{-122 .}$

Fléchier Esprit, Oraisons funèbres, 2 vols. (Paris, Antoine Dezallier: 1691).

Fromentières Jean-Louis de, Oraison funèbre d'Anne d'Autriche, Infante d'Espagne, Reine de France, et Mère du Roi, prononcée dans l'église des Martyrs à Montmartre le 6 mars 1666 (Paris, S. Mabre-Cramoisy: 1666).

Gaillard Honoré, "Oraison funèbre de Très-Haut, Très-Puissant et Excellent Prince Monseigneur Louis Dauphin; et de Très-Haute, Très-Puissante et Excellente Princesse Madame Marie Adélaïde de Savoye, son Epouse, prononcée dans l'Église de Paris, le dixième Mai 1712", in Oraisons funèbres des dauphins de France et de la Dauphine, Par Mr l'Evêque d'Alet, le Père Gaillard, le Père de la Rue, \&cc. On y a joint le Recueil des Vertus du Duc de Bourgogne, \& ensuite Dauphin, pour servir à l'Education d'un Grand Prince, Par le R.P. Martineau son Confesseur (Amsterdam, J. Desbordes \& L. Renard: 1713). 
Göttler Ch. - Enenkel K.A.E. (eds.), Solitudo: Spaces, Places, and Times of Solitude in Late Medieval and Early Modern Cultures (Boston: 2018).

Goujon P., Les Politiques de l'âme. Direction spirituelle et jésuites français à l'époque moderne (Paris: 2019).

Hall E., The Hidden Dimension (Garden City, N.Y.: 1966).

Lagorgette D., "Termes d'adresse et insultes: discours sur l'autre ou sur moi?", in Ayres-Bennett W. - Jones M.C. (eds.), The French Language and Questions of ldentity (Cambridge: 2007) 116-128.

"Livres nouveaux qui se trouveront à Lyon chez le Sieur Amaulry; depuis l'année 1678, jusqu'à présent", bound with Mercure Galant dédié à Monseigneur le Dauphin. Avril 1685 (Lyon, Thomas Amaulry: 1685), located at the Bibliothèque de la Ville de Lyon.

Martin P., Une religion des livres (1640-1850) (Paris: 2003).

Martineau Isaac, Recueil des vertus de Louis de France, Duc de Bourgogne, \& ensuite Dauphin (Paris, Jean Mariette: 1712).

Massillon Jean-Baptiste, "Oraison funèbre de Madame, Duchesse d'Orléans", in Massillon, Jean-Baptiste, Sermons de M. Massillon, Évêque de Clermont, vol. 9, Oraisons funèbres et Professions religieuses (Paris, Chez les Frères Estienne: 1775).

Papasogli B., Figures de l'espace intérieur au XVII e siècle, Le fond du cœur (Paris: 2000).

Quantin J.-L., "Paradoxes of Christian Solitude in the Seventeenth Century", Journal of Early Modern Christianity 1.2 (2014) 219-231.

Rapin René, Du Grand ou du sublime dans les mours et les différentes conditions des hommes (Paris, Mabre-Cramoisy: 1686).

Rapin René, Le Magnanime ou l'éloge du prince de Condé (Paris, Veuve Mabre-Cramoisy: 1687).

Soria Bonaventure de, Abrégé de la vie de très-auguste et très vertueuse princesse Marie Térèse d'Austriche, reyne de France et de Navarre, par le R. P. Bonnaventure de Soria, son confesseur, et son Oraison funèbre prononcé à Saint-Denis le 1er de septembre 1683 par Messire Jacques-Bénigne Bossuet, évesque de Meaux. Description de la décoration funèbre de Saint-Denis pour les obsèques de la reyne. Mausolée dressé dans l'église de Nostre-Dame de Paris au service solennel célébré pour le repos de l'âme de la reyne (Paris, Lambert Roulland:1683). 